DOI: $10.19195 / 0137-1134.109 .17$

\author{
ADRIAN SZUMSKI \\ Uniwersytet Wrocławski
}

\title{
TERRORYZM EKOLOGICZNY JAKO PRZESTĘPSTWO
}

W ostatnich dziesięcioleciach coraz większą uwagę przywiązuje się do ochrony środowiska. Kwestie te są obecnie przedmiotem zainteresowania nie tylko rządów i organizacji międzynarodowych, lecz także różnych formalnych i nieformalnych ugrupowań stawiających sobie za cel (w założeniu) dobro otaczającego nas środowiska. Zainteresowanie to znajduje odzwierciedlenie z jednej strony w przyjmowaniu coraz doskonalszych regulacji prawnych czy działalności propagującej dbałość o ekosystemy, $\mathrm{z}$ drugiej zaś - w różnych przejawach aktywności, którą nie zawsze można uznać za legalną, niezależnie od idei przyświecających osobom podejmującym taką aktywność. Rodzajem takiej, bez wątpienia bezprawnej, działalności jest terroryzm ekologiczny stanowiący coraz większy problem dla funkcjonowania państw i społeczeństw. Celem niniejszego artykułu jest próba umiejscowienia terroryzmu ekologicznego wśród czynów penalizowanych przez polskie prawo karne.

Termin ,terroryzm ekologiczny” (,ekoterroryzm”) nie jest jednolicie ujmowany w nauce. Niekiedy w publicystyce kwalifikuje się pod to pojęcie różne, nieznane dotąd zagrożenia ekologiczne, których potencjalne skutki mogą dotknąć społeczność międzynarodową, a które to zagrożenia nie są jeszcze do końca rozpoznane1. Czasami określa się tym mianem po prostu spektakularną działalność organizacji pozarządowych, której przedmiotem jest szeroko pojęta ekologia ${ }^{2}$. Terroryzm ekologiczny jest też interpretowany jako rodzaj działań przestępczych, których celem jest dokonanie zniszczeń $\mathrm{w}$ środowisku naturalnym albo sama groźba takiego ata$\mathrm{ku}^{3}$. Jak podkreśla się w literaturze, ekoterroryzm opiera się na założeniu, że źródłem wszelkiego zła na świecie jest współczesna cywilizacja, a w celu oczyszczenia środowiska naturalnego prawnie dozwolone może być każde działanie skierowane przeciwko tej cywilizacji (np. akcje niszczenia elektrowni jądrowych, tankowców) ${ }^{4}$.

1 J. Ciechanowicz-Mc Lean, Prawo i polityka ochrony środowiska, Warszawa 2009, s. 72.

2 Ibidem.

3 Zob. B. Hołyst, Terroryzm, t. 1, Warszawa 2011, s. 726.

4 R.A. Kosta, Terroryzm jako zagrożenie dla bezpieczeństwa cywilizacji zachodniej $w$ XX wie$k u$, Toruń 2007, s. 29. 
Przyjmując za kryterium rozróżnienia źródła inspiracji ideowej i cele ataku, można wyodrębnić dwa rodzaje ekoterroryzmu:

- ekoterroryzm instrumentalny (tzw. ekologiczny szantaż), w którym działanie terrorysty nie ma żadnego związku z realizacją idei związanych ze środowiskiem, a wręcz może być ich zaprzeczeniem. Osobom podejmującym takie działania chodzi o wywołanie powszechnego przerażenia możliwymi następstwami ataku i efektami wywołanymi w środowisku naturalnym na znacznym obszarze;

- ekoterroryzm millenarystyczny (określany też jako ekoterroryzm właściwy) — jego formą jest z kolei ekosabotaż, pod pojęciem którego należy rozumieć akty wandalizmu wymierzone przeciwko przedmiotom i obiektom postrzeganym jako symbole konsumpcjonizmus.

Odnosząc się do opisanych skrótowo sposobów definiowania terroryzmu ekologicznego, trzeba stwierdzić, że może być on różnie rozumiany. Przyjmując za kryterium motywy ideologiczne, którymi kierują się „ekoterroryści”, może to być zatem działalność motywowana ściśle troską o środowisko (w rozumieniu autorów takich akcji) bądź też aktywność, w której czynnik ekologiczny schodzi na dalszy plan, towarzyszy motywacjom antykonsumpcyjnym, antysystemowym itd.

Z kolei przyjmując za podstawę podziału sposób oraz skutki działania „ekoterrorystów", należy stwierdzić, że takie czyny mogą wyczerpywać znamiona przestępstwa bądź też mogą to być akcje propagandowe czy przypominające przejawy obywatelskiego nieposłuszeństwa, jednak nienaruszające dóbr chronionych prawem. W związku z tym organizacje zwane potocznie ruchami ekologicznymi można podzielić na dwie grupy: pierwszą stanowią „obrońcy przyrody” z determinacją dążący do celu, dokonując przy tym nawet spektakularnych działań (np. przywiązywanie się do drzew), drugą natomiast osoby, które przedstawiając swoje racje, częściej posługują się przemocą, zastraszaniem i niszczeniem mienia, po to, aby w ten sposób zaakcentować swoją postawę w obronie środowiska ${ }^{6}$.

Przechodząc do zagadnienia prawnej odpowiedzialności za czyny mogące zostać zaliczone do terroryzmu ekologicznego, warto zauważyć, że regulacje prawne dotyczące tego typu przestępczości funkcjonują za granicą. W literaturze słusznie podkreśla się przy tym, że rola przepisów prawnokarnych w ochronie środowiska naturalnego jest subsydiarna ${ }^{7}$. Do tego rodzaju aktów prawnych należy chociażby obowiązująca w Stanach Zjednoczonych Ameryki ustawa Animal Enterprise Protection Act of 1992, zmieniona i przemianowana w 2006 r. na Animal Enterprise Terrorism Act, uwzględniona w Rozdziale 3 Tytułu 18 Kodeksu Stanów Zjednoczonych (United States Code). W świetle tego aktu prawnego odpowiedzialność

5 R. Borkowski, Terroryzm ponowoczesny. Studium z antropologii polityki, Torun 2006, s. $248-249$.

${ }^{6}$ B. Uhlig, Ekoterroryzm?, „Zielone Brygady” 2001, nr 5, cyt. za: J. Ciechanowicz-Mc Lean, op. cit., s. 68-69.

7 W. Radecki, Odpowiedzialność karna za naruszenie środowiska w świetle prawa międzynarodowego, Wrocław 1981, s. 11. 
karną ponosi osoba, która w celu wyrządzenia szkód lub wpłynięcia na działalność przedsiębiorstwa wykorzystującego zwierzęta oraz w związku z tym celem:

— umyślnie uszkadza lub powoduje stratę jakiejkolwiek nieruchomości lub rzeczy ruchomej (w tym zwierząt lub dokumentów), używanej przez przedsiębiorstwo wykorzystujące zwierzęta albo jakiejkolwiek nieruchomości lub rzeczy ruchomej należącej do osoby bądź podmiotu związanego z takim przedsiębiorstwem osobiście lub stosunkami handlowymi;

— świadomie wywołuje poczucie groźby utraty życia lub poważnego uszkodzenia ciała u innej osoby, członka jej najbliższej rodziny, małżonka lub zażyłego partnera, w wyniku zachowania obejmującego groźbę, akty wandalizmu, uszkodzenie własności, naruszenie miru domowego, molestowanie lub zastraszanie; albo

— dopuszcza się zmowy lub usiłowania w celu dokonania któregoś z ww. czynów.

Użyty w tym przepisie zwrot „przedsiębiorstwo wykorzystujące zwierzęta” (animal enterprise) jest przy tym rozumiany szeroko i obejmuje:

- podmioty komercyjne lub akademickie, które wykorzystują lub sprzedają zwierzęta albo produkty pochodzenia zwierzęcego dla osiągnięcia zysku, w celu produkcji żywności lub włókna, w celach rolniczych, edukacyjnych, badawczych lub testowych;

- ogrody zoologiczne, akwaria, schroniska dla zwierząt, sklepy ze zwierzętami, hodowle, zakłady futrzarskie, cyrki lub rodea bądź organizowanie innych, zgodnych z prawem imprez z udziałem zwierząt;

— jakąkolwiek inną uczciwą działalność zmierzającą do postępu w dziedzinie rolnictwa lub nauki.

Aktem prawnym obowiązującym w Stanach Zjednoczonych, mogącym stanowić podstawę odpowiedzialności za działalność „ekoterrorystyczną” jest także USA Patriot Act of 2001, mający w założeniu m.in. lepiej chronić państwo przed zamachami terrorystycznymi, w tym także przed aktami ekoterroryzmu ${ }^{8}$.

Warto też nadmienić, że przestępstwo przeciwko środowisku może być uznane za przestępstwo międzynarodowe, pod warunkiem jednak, że występują następujące przesłanki ${ }^{9}$ :

— jest ono jedną z postaci zbrodni wojennych przez naruszenie Protokołu dodatkowego do Konwencji genewskich o ochronie ofiar wojny;

- stanowi agresję ekologiczną;

— jest jedną z postaci ludobójstwa określoną w art. 2 pkt c) konwencji o ludobójstwie, przy założeniu, że zamiarem sprawcy jest zniszczenie w całości lub w części grup narodowych, etnicznych, rasowych lub religijnych jako takich ${ }^{10}$.

\footnotetext{
8 Zob. D. Long, Ecoterrorism, New York 2004, s. 62-66.

9 W. Radecki, op. cit., s. 118.

10 Ibidem, s. 114.
} 
Natomiast odnosząc się do polskich regulacji prawnych, należy przede wszystkim stwierdzić, że polski Kodeks karny nie zawiera definicji terroryzmu ekologicznego. Udzielając odpowiedzi na pytanie o jego umiejscowienie wśród czynów penalizowanych przez polskie prawo karne, należałoby zastanowić się nad prawnym znaczeniem obydwu sformułowań tworzących to pojęcie.

W pierwszej kolejności konieczne wydaje się wyjaśnienie pojęcia terroryzmu. Odnosząc się wyłącznie do ujęcia normatywnego i nie wchodząc w liczne definicje tego pojęcia, z którymi można spotkać się w literaturze politologicznej, trzeba zauważyć, że polski Kodeks karny posługuje się w art. $115 \S 20$ terminem „przestępstwa o charakterze terrorystycznym”. Warto w tym miejscu dodać, że przepis ten jest konsekwencją wdrożenia do prawa polskiego Decyzji ramowej UE z 13 kwietnia 2002 r. w sprawie zwalczania terroryzmu. Decyzja ta stwierdza, że za przestępstwa terrorystyczne uważane są:

— ataki na życie ludzkie, które mogą spowodować śmierć;

— ataki na integralność cielesną osoby;

— porwania lub branie zakładników;

- spowodowanie rozległych zniszczeń obiektów rządowych lub obiektów użyteczności publicznej, systemu transportowego, infrastruktury, łącznie ze zniszczeniem systemu informacyjnego, stałych platform umieszczonych na szelfie kontynentalnym, miejsca publicznego lub mienia prywatnego, mogące zagrozić życiu ludzkiemu lub mogące spowodować poważne straty gospodarcze;

— zajęcie statku powietrznego, statku lub innego środka transportu publicznego lub towarowego;

- wytwarzanie, posiadanie, nabywanie, przewożenie, dostarczanie lub używanie broni, materiałów wybuchowych lub jądrowych, broni biologicznej lub chemicznej, jak również badania i rozwój broni biologicznej i chemicznej;

- uwalnianie substancji niebezpiecznych lub powodowanie pożarów, powodzi lub wybuchów, których rezultatem jest zagrożenie życia ludzkiego;

— zakłócenia lub przerwy w dostawach wody, energii elektrycznej lub wszelkich innych podstawowych zasobów naturalnych, których rezultatem jest zagrożenie życia ludzkiego;

— grożenie popełnieniem ww. czynów.

Wracając do regulacji polskiego Kodeksu karnego, należy zaznaczyć, że wspomniany art. $115 \S 20$ k.k. stanowi, iż przestępstwem o charakterze terrorystycznym jest

czyn zabroniony zagrożony karą pozbawienia wolności, której górna granica wynosi co najmniej 5 lat, popełniony w celu:

1. poważnego zastraszenia wielu osób;

2. zmuszenia organu władzy publicznej Rzeczypospolitej Polskiej lub innego państwa albo organu organizacji międzynarodowej do podjęcia lub zaniechania określonych czynności;

3. wywołania poważnych zakłóceń w ustroju lub gospodarce Rzeczypospolitej Polskiej, innego państwa lub organizacji międzynarodowej — a także groźba popełnienia takiego czynu. 
Przepis ten wprowadza swego rodzaju dychotomiczny podział przestępstw na przestępstwa o charakterze terrorystycznym oraz inne przestępstwa ${ }^{11}$. Przechodząc do jego analizy, należy w pierwszej kolejności zwrócić uwagę na to, że przestępstwem o charakterze terrorystycznym w świetle Kodeksu karnego jest czyn zagrożony karą pozbawienia wolności, której górna granica wynosi co najmniej 5 lat. Pojawia się w związku z tym pytanie, czy przestępstwem o charakterze terrorystycznym może być każdy czyn o takim zagrożeniu karą. Wydaje się, że odpowiedź na to pytanie jest negatywna. Istnieje bowiem wiele przestępstw o zagrożeniu sięgającym kary 5 lat pozbawienia wolności (np. przestępstwo bigamii czy niealimentacji), przy których popełnieniu trudno wyobrazić sobie dążenie do osiągnięcia któregoś z celów, o których mowa w art. 115 § 20 k.k. Tak więc niektóre przestępstwa mogą być wykorzystane do realizacji celu terrorystycznego, inne natomiast - nawet gdyby dokonywać ich oceny in abstracto — zupełnie się do tego nie nadają ${ }^{12}$.

Artykuł $115 \S 20$ k.k. wylicza enumeratywnie cele składające się na istotę przestępstwa o charakterze terrorystycznym. Warto w tym miejscu poświęcić nieco uwagi sformułowaniom użytym w powyższym wyliczeniu. I tak, jeśli chodzi o „poważne zastraszanie wielu osób”, jest to zwrot wysoce ocenny. Pod pojęciem zastraszania należy rozumieć wywołanie przerażenia straszeniem, groźbami, doprowadzenie do stanu lęku, niepokoju. Dla odpowiedzialności karnej za przestępstwo o charakterze terrorystycznym jest przy tym obojętne, w jaki sposób i przy użyciu jakich środków sprawca zmierzał do wywołania takiego stanu ${ }^{13}$. Zastraszanie to powinno być „poważne”, a więc (zgodnie z potocznym rozumieniem) takie, którego nie należy lekceważyć, ważne, niemałe, znaczące. Kryteriami pomocnymi w ocenie stopnia zastraszenia może być jego zasięg personalny lub przestrzenny, wysokie prawdopodobieństwo nastąpienia grożącego zdarzenia czy też rozmiary tego zdarzenia ${ }^{14}$. Ponadto zastraszenie to powinno dotyczyć „wielu osób”, co również jest pojęciem nieostrym. Wprawdzie niekiedy w literaturze próbuje się ustalić minimalną liczbę spełniającą kryterium „wielości osób” w kontekście art. 115 $\S 20$ k.k. ${ }^{15}$, wydaje się jednak, że tworzenie takiej granicy nie jest najwłaściwsze, lecz, ustalając, czy w danym przypadku mamy do czynienia z „wieloma osobami”, zawsze należy brać pod uwagę całokształt okoliczności konkretnej sprawy ${ }^{16}$.

11 C. Sońta, Przestępstwo o charakterze terrorystycznym, „Wojskowy Przegląd Prawniczy” 2005, nr 4, s. 13.

12 Kodeks karny. Część ogólna. Komentarz, red. J. Giezek, Warszawa 2012, s. 739.

13 Kodeks karny. Komentarz, red. A. Grześkowiak, K. Wiak, Warszawa 2014, s. 571.

14 Kodeks karny. Komentarz, red. M. Filar, Warszawa 2012, s. 638.

15 Zob. np. Kodeks karny. Komentarz, red. T. Bojarski, Warszawa 2013, s. 282.

16 Zob. K. Wiak, Przestępstwa o charakterze terrorystycznym i ich konsekwencje $w$ świetle przepisów kodeksu karnego, [w:] Zmiany w polskim prawie karnym po wejściu w życie kodeksu karnego z 1997 roku, red. T. Bojarski et al., Lublin 2006, s. 318-319. 
Drugim celem, o którym wspomina art. $115 \S 20$ k.k., jest zmuszenie organu władzy publicznej Rzeczypospolitej Polskiej lub innego państwa albo organu organizacji międzynarodowej do podjęcia lub zaniechania określonych czynności. „Zmuszenie organu” należy tutaj rozumieć jako nakłonienie go do określonego zachowania wbrew jego woli. Organami władzy publicznej są przy tym wszystkie organy wykonujące taką władzę, a więc organy państwowe, samorządu terytorialnego, zarówno polskie, jak i obce ${ }^{17}$. Natomiast jeśli chodzi o organizacje międzynarodowe, to pojęcie to należy rozumieć szeroko, zaliczając tutaj zarówno organizacje rządowe, jak i pozarządowe. Przedmiotem zmuszenia będzie podjęcie lub zaniechanie przez takie organy „określonych czynności”. Ustawa nie wskazuje niestety ani ich kierunku, ani rodzaju. Użyty w niej zwrot „określone” oznacza jednak, że muszą być one przez wymuszającego sprecyzowane. Wymuszoną może być zatem jakakolwiek czynność, pod warunkiem, że jej treść została dostatecznie sprecyzowana $^{18}$.

Wreszcie trzeci element wyliczenia zawarty w art. $115 \S 20$ k.k. to „wywołanie, a także groźba wywołania poważnych zakłóceń w ustroju lub gospodarce Rzeczypospolitej Polskiej, innego państwa lub organizacji międzynarodowej”. Takimi zakłóceniami będzie przy tym powodowanie takiego zaburzenia zwykłego funkcjonowania państwa czy organizacji międzynarodowej, które w znaczący sposób utrudnia ich normalne działanie. Kryterium to, podobnie jak dwa wymienione wcześniej, jest jednak również w dużym stopniu ocenne, w związku z tym wymaga wzięcia pod uwagę całokształtu danego stanu faktycznego. W szczególności to, czy zakłócenia były „poważne”, wymaga oceny z uwzględnieniem specyfiki funkcjonowania tego elementu ustroju lub gospodarki, w który sprawca chciał ugodzić19. Z kolei zawarte na końcu sformułowanie „groźba popełnienia takiego czynu" oznacza odrębny czyn zabroniony, mogący stanowić przestępstwo o charakterze terrorystycznym ${ }^{20}$. Nie jest przy tym konieczne, aby takie zachowanie sprawcy odpowiadało typowi przestępstwa zagrożonego karą pozbawienia wolności, której górna granica wynosi co najmniej 5 lat. Warunek ten odnosi się bowiem jedynie do czynu zabronionego stanowiącego treść groźby.

Nie ulega wątpliwości, że definicja przestępstwa o charakterze terrorystycznym jest $w$ świetle omawianego przepisu bardzo szeroka. Może ona bowiem obejmować wiele czynów przeciwko różnym podmiotom oraz dobrom chronionym prawem, w tym przeciwko środowisku. Należy jednak zaznaczyć, że środowisko stanowi tutaj jedynie pośredni cel ataków terrorystycznych, zaś spowodowanie strat w środowisku lub jego elementach może służyć raczej jako środek do realizacji przez terrorystów innych celów ${ }^{21}$.

17 Prawo karne materialne: część ogólna, red. M. Mozgawa, Warszawa 2011, s. 440.

18 Kodeks karny. Komentarz, red. M. Filar, s. 639.

19 Kodeks karny. Komentarz, red. T. Bojarski, s. 283.

20 Kodeks karny. Komentarz, red. A. Grześkowiak, K. Wiak, s. 573.

21 J. Ciechanowicz-McLean, op. cit., s. 71. 
W literaturze słusznie podkreśla się, że przestępstwa o charakterze terrorystycznym mają charakter celowy, zmierzający do osiągnięcia określonego efektu, bezpośrednie ofiary zamachu są zaś najczęściej traktowane jako środki do realizacji tego celu. Jednocześnie przestępstwo nie traci charakteru terrorystycznego ze względu na motywy kierujące sprawcą, jeżeli spełnia warunki przewidziane w art. $115 \S 20$ k.k. ${ }^{22}$ Użyty w powyższym przepisie zwrot „popełniony w celu” może jednak budzić pewne wątpliwości. Można stąd bowiem wyciągnąć wniosek, że elementy wymienione w pkt 1-3 określają cele, a nie czyny składające się na przestępstwo o charakterze terrorystycznym, tymczasem zaś dla jego popełnienia zrealizowanie wyznaczonych przestępstwu celów nie jest konieczne. W tym kontekście użyty w art. $115 \S 20$ pkt 3 in fine zwrot ,a także groźba popełnienia takiego czynu" może sugerować, że w tej części opisywanego przepisu został określony czyn stanowiący przestępstwo o charakterze terrorystycznym, a nie cel kreujący taki charakter czynu ${ }^{23}$.

Wątpliwości mogą budzić też wspomniane już, zawarte w art. $115 \S 20$ k.k., zwroty niedookreślone, takie jak „poważne zastraszenie wielu osób”, „podjęcie lub zaniechanie określonych czynności” czy „wywołanie poważnych zakłóceń w ustroju lub gospodarce". Odwołanie się przez ustawodawcę do tego typu trudnych do zmierzenia w sposób zobiektywizowany określeń sprawia, że na organie stosującym prawo spoczywa szczególna odpowiedzialność przy kwalifikowaniu danego czynu jako przestępstwa o charakterze terrorystycznym.

Niewątpliwym mankamentem omawianego przepisu jest brak konkretnych wskazówek odnośnie do tego, czy karalne jest przygotowanie do przestępstwa terrorystycznego. Pod tym względem należy stwierdzić, że poszczególne przestępstwa poprzedzające atak terrorystyczny (np. kradzież samochodu, który ma zostać użyty w zamachu) stanowią jedynie pewne etapy na drodze do celu określonego w przestępstwie o charakterze terrorystycznym. O istnieniu celu terrorystycznego w tego typu czynach zabronionych, najbardziej oddalonych od jego faktycznej realizacji, decydować będzie zatem powiązanie go z kolejnymi przestępstwami zmierzającymi do jego urzeczywistnienia ${ }^{24}$.

Wreszcie pojawia się problem, jak kwalifikować i opisać przestępstwo o charakterze terrorystycznym. W literaturze słusznie podkreśla się, że obowiązujące w Polsce przepisy karne służące zwalczaniu terroryzmu nie pozwalają (w zasadzie) na wykazanie zarówno w opisie czynu, jak i w jego kwalifikacji prawnej, że mamy do czynienia z popełnieniem przestępstwa o charakterze terrorystycznym. Brakuje bowiem w regulacjach Kodeksu karnego (poza definicją) szczegółowego zespołu znamion (zwłaszcza podmiotowych), który w opisie czynu pozwalałby

22 A. Marek, Kodeks karny. Komentarz, Warszawa 2007, s. 272.

23 O. Górniok, Przestepstwo o charakterze terrorystycznym w art.115 § 20 k.k., „Przegląd Sądowy" 2004, nr 10, s. 10-11.

${ }_{24}$ T. Przesławski, Cel w konstrukcji przestepstwa terrorystycznego, „Prokuratura i Prawo” 2009, nr 5, s. 26. 
oddać, iż danego czynu zabronionego dokonano w celu terrorystycznym. Nie ma również możliwości wykazania w kwalifikacji prawnej czynu, że doszło do realizacji przestępstwa o charakterze terrorystycznym. Kwalifikowanie konkretnego czynu zabronionego w związku z art. $115 \S 20$ k.k., dla oddania zawartości bezprawia tkwiącego $\mathrm{w}$ przestępstwie o charakterze terrorystycznym, nie byłoby bowiem poprawne ${ }^{25}$.

Ważnym uzupełnieniem regulacji zawartej w art. $115 \S 20$ k.k. jest ustawa z 16 listopada 2000 r. o przeciwdziałaniu praniu pieniędzy oraz finansowaniu terroryzmu (Dz.U. $2003 \mathrm{Nr}$ 153, poz. 1505 ze zm.) oraz ustawa z 25 czerwca 2009 r. o zmianie ustawy o przeciwdziałaniu wprowadzaniu do obrotu finansowego wartości majątkowych pochodzących z nielegalnych lub nieujawnionych źródeł oraz o przeciwdziałaniu finansowaniu terroryzmu oraz o zmianie niektórych innych ustaw (Dz.U. 2009 Nr 166, poz. 1317). Warto zwrócić uwagę zwłaszcza na drugi $\mathrm{z}$ tych aktów prawnych. Ustawa ta, oprócz zmiany tytułu ustawy z 16 listopada 2000 r. (jej pierwotna nazwa to ustawa o przeciwdziałaniu wprowadzaniu do obrotu finansowego wartości majątkowych pochodzących z nielegalnych lub nieujawnionych źródeł oraz o przeciwdziałaniu finansowaniu terroryzmu), wprowadziła do Kodeksu karnego art. 165a, który określa nowe przestępstwo finansowego wspierania terroryzmu. Zgodnie z tym przepisem:

Kto gromadzi, przekazuje lub oferuje środki płatnicze, instrumenty finansowe, papiery wartościowe, wartości dewizowe, prawa majątkowe lub inne mienie ruchome lub nieruchomości w zamiarze sfinansowania przestępstwa o charakterze terrorystycznym lub przestępstwa, o którym mowa w art. 120, art. 121, art. 136, art. 166, art. 167, art. 171, art. 252, art. 255a lub art. 259a, podlega karze pozbawienia wolności od lat 2 do 12 .

Uznanie przestępstwa za mające charakter terrorystyczny pociąga za sobą określone konsekwencje z punktu widzenia regulacji karnoprawnych. Dotyczy to przede wszystkim wymiaru kary, środków karnych oraz środków związanych z poddaniem sprawcy próbie. Pod tym względem art. $65 \S 1$ k.k. odsyła do art. 64 $\S 2$ k.k., przewidującego nadzwyczajne obostrzenie kary w razie spełnienia zawartych w nim przesłanek. Na mocy tego przepisu sąd ma bowiem obowiązek wymierzenia kary pozbawienia wolności w wysokości powyżej dolnej granicy ustawowego zagrożenia, a może ją wymierzyć do górnej granicy ustawowego zagrożenia zwiększonego o połowę. Podwyższenie górnego ustawowego zagrożenia nie dotyczy jednak zbrodni (art. $64 \S 3$ k.k.). Z kolei jeżeli występuje zbieg niezależnych od siebie podstaw do nadzwyczajnego obostrzenia kar, sąd (zgodnie z art. $57 \S 1$ k.k.) może tylko jeden raz nadzwyczajnie obostrzyć karę, biorąc pod uwagę łącznie zbiegające się podstawy obostrzenia. Natomiast w wypadku zbiegu podstaw nadzwyczajnego obostrzenia i nadzwyczajnego złagodzenia sąd może zastosować nadzwyczajne złagodzenie albo obostrzenie kary (art. $57 \S 2$ k.k.).

25 R. Zgorzały, Przestepstwo o charakterze terrorystycznym $w$ polskim prawie karnym, „Prokuratura i Prawo” 2007, nr 7-8, s. 67. 
W odniesieniu do przestępstw o charakterze terrorystycznym nie ma przy tym możliwości warunkowego umorzenia postępowania. Przeszkodą jest tutaj art. 66 $\S 2$ k.k., stanowiący, że instytucji tej nie stosuje się do sprawcy przestępstwa zagrożonego karą przekraczającą 5 lata pozbawienia wolności.

Ograniczone są też możliwości warunkowego przedterminowego zwolnienia sprawcy przestępstwa o charakterze terrorystycznym. Podobnie jak w odniesieniu do innych przestępstw, wymagane jest tutaj spełnienie warunku pozytywnej prognozy, o którym mowa w art. 77 § 1 k.k., ale art. 78 § 2 k.k. zaostrza ten warunek, dopuszczając możliwość warunkowego zwolnienia po odbyciu przez skazanego trzech czwartych kary.

Wreszcie, konsekwencją uznania przestępstwa za terrorystyczne może być zastosowanie przez sąd tymczasowego aresztowania oskarżonego o takie przestępstwo, na podstawie przesłanki grożącej surowej kary (gdy występuje podstawa ogólna z art. 249 § 1 k.p.k. i szczególna z art. 258 § 3 k.p.k.).

Przechodząc do rozważań nad drugim członem terminu „terroryzm ekologiczny”, należy podkreślić, że zwrot „ekologiczny” będzie się tutaj odnosił do oddziaływania na środowisko naturalne. Warto w tym miejscu zwrócić uwagę na częste nadużywanie sformułowań „ekologia” czy „ekologiczny”26 oraz błędne utożsamianie, w języku potocznym, wyrażeń „ekologia” i „ochrona środowiska”. Dziennikarze oraz członkowie różnych organizacji „zielonych” traktują bowiem niejednokrotnie ekologię jako rodzaj subkultury masowej ${ }^{27}$ i stosują ten termin nagminnie, nie zawsze zgodnie z jego właściwym znaczeniem. Tymczasem ekologia, będąc nauką, ma sprecyzowany zakres, własne hipotezy i teorie badawcze, własną metodę i metodologię badań. Należy zatem dokonać wyraźnego rozróżnienia pomiędzy terminami „ochrona środowiska” i „ekologia”. Pierwsze z tych pojęć oznacza „ogół czynności praktycznych mających za zadanie niedopuszczenie do zanieczyszczania środowiska, jego niszczenia, degradacji, skażania lub przekształcania" 28 . Natomiast ekologia to ,jedna z dziedzin nauk przyrodniczych, nauka o strukturze i funkcjonowaniu przyrody, zajmująca się badaniem oddziaływań pomiędzy organizmami a ich środowiskiem"29.

Jeśli chodzi o regulacje zawarte w Kodeksie karnym, to w pewnym zakresie odnosi się on wprost do przestępczych działań związanych ze środowiskiem naturalnym. Penalizuje bowiem przestępstwa przeciwko środowisku, które zawarte są w rozdziale XXII k.k. i obejmują:

${ }^{26}$ Nadużywanie to wynika być może z braku polskiego odpowiednika angielskiego terminu environmental, zob. J. Jędrośka, M. Bar, Prawo ochrony środowiska. Podręcznik, Wrocław 2005, s. 21.

27 J. Stochlak, M. Podolak, Ochrona środowiska w Polsce. Studium prawno-politologiczne, Lublin 2006, s. 29.

28 J. Boć, E. Samborska-Boć, K. Nowacki, Ochrona środowiska, Wrocław 2005, s. 55.

29 J. Jędrośka, M. Bar, op. cit., s. 20. Zob. też H. Lisicka, I. Macek, W. Radecki, Leksykon ochrony środowiska. Prawo i polityka, Wrocław 1999, s. 33. 
— zniszczenia w przyrodzie (art. 181);

— zanieczyszczanie środowiska (art. 182);

- przestępstwa $\mathrm{w}$ zakresie postępowania $\mathrm{z}$ odpadami lub substancjami (art. 183);

— przestępstwa w zakresie postępowania z materiałami promieniotwórczymi (art. 184);

— kwalifikowane typy ww. przestępstw przeciwko środowisku (art. 185);

— niedopełnienie obowiązków dbałości o urządzenia zabezpieczające środowisko (art. 186);

— niszczenie i uszkadzanie terenów oraz obiektów chronionych (art. 187);

— szkodliwą działalność zagrażającą środowisku (art. 188).

Przestępstwa te można podzielić na dwie zasadnicze grupy. Pierwszą stanowią przestępstwa powodowania zanieczyszczeń i innych zagrożeń środowiska (art. 182-186). Druga natomiast (art. $181 \S 1$ i 4, art. 181 § 2 i 5, art. 181 § 3 i 5, art. 187-188) odnosi się do przestępstw przeciwko zasobom przyrodniczym i tradycyjnej ochronie przyrody ${ }^{30}$. Przestępstwa te mogą mieć charakter materialny (wszystkie przestępstwa $z$ art. 181, art. $183 \S 2$, art. 185, art. 187) lub formalny (art. 182, art. $183 \S 1$, art. 184, art. 186, art. 188). Wszystkie przestępstwa z rozdziału XXII k.k. są występkami ściganymi z oskarżenia publicznego, z urzędu ${ }^{31}$.

Pojawia się tutaj pytanie, czy ww. przestępstwa mogą nosić znamiona terroryzmu ekologicznego. $Z$ jednej strony cechą, która mogłaby zbliżać te czyny do działań terrorystycznych, jest to, że odpowiedzialność karna w świetle wspomnianych przepisów może niejednokrotnie dotyczyć szkód powstałych w sposób gwałtowny, widoczny i ewidentnie odczuwalny. Podczas rozpatrywania samej konstrukcji, zarówno w art. $115 \S 20$ k.k., jak i w wypadku przestępstw z rozdziału XXII k.k., dostrzegalna jest też obecność znamion ocennych (w tym ostatnim wypadku jest to przede wszystkim pojęcie istotnej szkody, zawarte w art. $181 \S 2$ i 3 oraz w art. 187 k.k.).

$\mathrm{Z}$ drugiej jednak strony cechą odróżniającą przestępstwa wymienione w rozdziale XXII od przestępstw o charakterze terrorystycznym jest to, że większość spośród tych pierwszych może być popełniona zarówno z winy umyślnej, jak i nieumyślnej (nie dotyczy to przestępstwa $\mathrm{z}$ art. 188, które może być popełnione tylko umyślnie). Ponadto na takie zakwalifikowanie wszystkich przestępstw z rozdziału XXII k.k. nie pozwala treść art. $115 \S 20$ k.k., który wyraźnie stwierdza, że przestępstwem o charakterze terrorystycznym może być jedynie czyn zagrożony karą pozbawienia wolności, której górna granica wynosi co najmniej 5 lat. Tymczasem warunek ten spełniają wyłącznie przestępstwa z art. $181 \S 1,182 \S 1$

30 Instytucje prawa ochrony środowiska. Geneza, rozwój, perspektywy, red. W. Radecki, Warszawa 2010, s. 432.

31 Kodeks karny. Komentarz, red. A. Grześkowiak, K. Wiak, s. 713. 
i 3, 183 § 1-5, 184 § 1 i 2 k.k., a także kwalifikowane typy przestępstw przeciwko środowisku (art. 185 k.k.).

Należy wyciągnąć stąd wniosek, że nie każde działanie, które w sensie politologicznym mogłoby potencjalnie zostać zakwalifikowane jako ekoterroryzm, nosi znamiona przestępstwa o charakterze terrorystycznym $\mathrm{w}$ świetle polskiego prawa karnego. Biorąc pod uwagę wyłącznie treść przepisów Kodeksu karnego, mogłoby się wydawać, że charakter terroryzmu ekologicznego mogą mieć niektóre $\mathrm{z}$ przestępstw wymienionych $\mathrm{w}$ rozdziale XXII k.k., a mianowicie te zagrożone karą pozbawienia wolności, której górna granica wynosi co najmniej 5 lat, spełniające warunki zawarte $w$ art. $115 \S 20$ pkt $1-3$ k.k. i pod warunkiem, że zostały popełnione z winy umyślnej. Analizując intencje ustawodawcy, wydaje się jednak, że w art. 182-185 k.k. ujęte zostały przestępstwa przeciwko środowisku jako uboczne, niepożądane skutki normalnej działalności gospodarczej, a zatem nie mogą one mieć nic wspólnego z terroryzmem. Inaczej natomiast będzie przedstawiała się sytuacja, w której mamy do czynienia z zamachem „,z zewnątrz”, kiedy np. grupa „ekoterrorystów” podczas realizowanej akcji wywoła pożar czy doprowadzi do rozprzestrzenienia się substancji trujących w taki sposób, że będzie to zagrażało życiu lub zdrowiu wielu osób albo mieniu w wielkich rozmiarach. Podstawą kwalifikacji będą tutaj jednak raczej przepisy rozdziału XX k.k., dotyczące przestępstw przeciwko bezpieczeństwu powszechnemu.

W ramach bardzo szeroko rozumianego pojęcia terroryzmu ekologicznego mogą mieścić się też inne działania, np. te podejmowane przez tzw. środowiska ekologiczne „w imię ratowania natury”; począwszy od blokowania dróg, zatrzymywania transportów z niebezpiecznymi odpadami, utrudniania połowów statkom rybackim, po niszczenie mienia podmiotów „wrogich środowisku”. W tym miejscu należy dokonać rozróżnienia pomiędzy terroryzmem ekologicznym a protestami.

Protest, w języku potocznym, to „energiczny, zdecydowany sprzeciw, wystąpienie skierowane przeciw czemuś, co uważa się za niesłuszne, niewłaściwe; opozycja, przeciwstawienie się"32. Protest jest zatem prawnie dopuszczalną formą wyrażania poglądów (gwarantowaną przez art. 54 ust. 1 Konstytucji RP i art. 10 ust.1 Konwencji o Ochronie Praw Człowieka i Podstawowych Wolności). Jednocześnie, jak stwierdził Trybunał Konstytucyjny, ,[...] wyrażenie »pogląd « powinno być rozumiane jak najszerzej, nie tylko jako wyrażanie osobistych ocen co do faktów i zjawisk we wszystkich przejawach życia, lecz również jako prezentowanie opinii, przypuszczeń i prognoz [...]"33. Tak rozumiane protesty z pewnością nie będą miały charakteru terroryzmu ekologicznego i będą dozwolone, dopóki ich forma nie narusza powszechnie obowiązujących przepisów, zwłaszcza karnych. O nielegalności protestu może zatem przesądzić dopiero jego forma polegająca

32 Słownik współczesnego języka polskiego, t. 2, red. A. Sikorska-Michalak, O. Wojniłko, Warszawa 1998, s. 157.

33 Wyrok TK z 5 maja 2004 r., P 2/03, Dz.U. 2004 Nr 111, poz. 1181. 
na zastosowaniu przemocy (także wobec rzeczy), blokowaniu dróg publicznych, zajmowania budynków publicznych itp. Nawet bowiem gdyby takie zachowania nie były karalne, $\mathrm{w}$ razie protestu wobec legalnie prowadzonych przedsięwzięć są one bezprawne ${ }^{34}$. Można też wyobrazić sobie sytuację, gdy forma protestu wypełni znamiona przestępstwa o charakterze terrorystycznym. Taki przypadek może mieć miejsce, gdy uczestnicy protestu będą dopuszczać się umyślnie np. czynów wyczerpujących znamiona przestępstwa z art. $288 \S 1$ lub 3 k.k., które są zagrożone karą pozbawienia wolności do lat 5 . Konieczne jest tutaj jednak, aby osoby popełniające takie przestępstwo dążyły do jednego z celów, o których mowa w art. $115 \S 20$ k.k.

Należałoby jeszcze spróbować odpowiedzieć na pytanie, czy na gruncie prawa polskiego celowe byłoby stworzenie kategorii przestępstwa terroryzmu ekologicznego i ustanowienia odrębnych sankcji karnych za tego rodzaju czyny. Wydaje się, że nie ma takiej potrzeby. Przede wszystkim, biorąc pod uwagę niejednoznaczność poglądów co do istoty tego zjawiska, trudności sprawiłoby stworzenie prawnej definicji terroryzmu ekologicznego. Taka definicja siłą rzeczy musiałaby się niewiele różnić od definicji przestępstwa o charakterze terrorystycznym. Podobnie jak ona, musiałaby kłaść nacisk na aspekt zastraszania społeczeństwa, wymuszania na organach władzy określonych zachowań czy wywoływania istotnych zakłóceń w funkcjonowaniu podmiotów państwowych lub międzynarodowych. Nie sposób bowiem objąc taką definicją różnego rodzaju akcji, nawet tych podejmowanych przez radykalne środowiska, ale które tak poważnego zagrożenia dla funkcjonowania państwa i społeczeństwa nie wywołują; trudno stawiać w jednym szeregu np. zamach na elektrownię atomową (motywowany dbałością o środowisko) z protestami (nawet uciążliwymi) przeciwko transportowi odpadów szkodliwych. Dlatego też podczas rozważania tych zagadnień konieczne jest w pierwszej kolejności zbadanie podstaw prawnych działalności organizacji stawiających sobie za cel ochronę środowiska oraz rozważenie, czy legalna działalność tych organizacji może być utożsamiana $z$ terroryzmem ekologicznym. Wydaje się, że odpowiedź będzie tutaj negatywna. Natomiast jeżeli jest to działalność nielegalna, wówczas będziemy mieli do czynienia z naruszeniem prawa skutkującym odpowiedzialnością ${ }^{35}$.

Argumentem przeciwko tworzeniu odrębnej definicji jest również fakt, że definicja taka w dalszym ciągu charakteryzowałaby się również znacznym stopniem ogólności. Z tych też względów wystarczające wydają się obecnie obowiązujące przepisy Kodeksu karnego. Artykuł $115 \S 20$ k.k. jest zatem podstawą odpowiedzialności za przestępstwa o charakterze terrorystycznym, wśród których, jak już wspomniano, mieszczą się także czyny zabronione, związane ze środowiskiem. Natomiast w wypadku czynów wypełniających znamiona przestępstwa, ale nie

34 W. Radecki, Legalność protestu, [w:] Ochrona środowiska w polityce, red. H. Lisicka, Wrocław 1999, s. 248.

35 J. Ciechanowicz-Mc Lean, op. cit., s. 68. 
spełniających warunków, o których mowa w art. $115 \S 20$ k.k., podstawą penalizacji (w zależności od ich zakwalifikowania) będą inne przepisy Kodeksu karnego (np. może to być art. 165 k.k. dotyczący sprowadzenia niebezpieczeństwa powszechnego czy wspomniane już przepisy rozdziału XXII k.k., odnoszące się do przestępstw przeciwko środowisku).

Pewne wątpliwości (oprócz tych wymienionych wcześniej) budzi natomiast kwestia finansowania terroryzmu ekologicznego. W Polsce (w odróżnieniu np. od Wielkiej Brytanii, gdzie rolę tę spełnia ustawa Terrorism Act 2000) nie ma odrębnych przepisów o odpowiedzialności karnej za finansowanie tego typu działalności. W wypadku przestępstw „terroryzmu ekologicznego” spełniających warunki, o których mowa w art. $115 \S 20$ k.k., zastosowanie będzie miał więc wspomniany już art. 165a k.k. Mankamentem tego przepisu jest jednak nieco rozbudowana definicja penalizowanego w nim przestępstwa, utrudniająca wykładnię pojęcia „finansowanie terroryzmu", z uwagi na konieczność stosowania podwójnego odesłania (art. 2 pkt 10 ustawy z 16 listopada 2000 r. odsyła do art. 165a k.k., który odsyła z kolei do art.115 § 20 k.k.), a dodatkowo stwarzająca komplikacje praktyczne. Zastosowanie art. 165a k.k. będzie bowiem wiązało się z koniecznością ustalenia, że sprawca gromadzi, przekazuje lub oferuje środki płatnicze w celu popełnienia przestępstwa, którego potencjalnym i „dalszym” celem będzie np. zmuszenie organu państwowego do określonego zachowania. Tymczasem na etapie, na którym nie doszło jeszcze do popełnienia przestępstwa o charakterze terrorystycznym, dla potrzeb popełnienia którego gromadzone są środki finansowe, ustalenie tego faktycznego „dalszego" celu może okazać się skomplikowane ${ }^{36}$. W tej sytuacji słuszny wydaje się prezentowany w literaturze postulat modyfikacji ujęcia przestępstwa finansowania terroryzmu, zgodnie z którym odpowiedzialność karną ponosiłby ten „Kto środki płatnicze, instrumenty finansowe, papiery wartościowe, wartości dewizowe, prawa majątkowe lub inne rzeczy ruchome lub nieruchomości gromadzi, przekazuje, oferuje lub podejmuje inne czynności prowadzące do ich wykorzystania do popełnienia przestępstwa o charakterze terrorystycznym". Słusznie bowiem podkreśla się, że dopuszczenie się wspomnianych czynności sprawczych, poszerzonych o uwzględnienie w nich także wykorzystania „w inny sposób" środków płatniczych, z zamiarem ich użycia do popełnienia przestępstwa o charakterze terrorystycznym (pomimo pozbawienia przestępstwa finansowania terroryzmu charakteru kierunkowego), będzie wystarczające dla oddania istoty tego uregulowania ${ }^{37}$. Celowym może być tutaj też odwołanie się do wiedzy posiadanej przez podmiot przestępstwa finansowania terroryzmu na temat popełnienia przestępstwa o charakterze terrorystycznym (np. sformułowanie „kto, mając informację dotyczącą popełnienia przestępstwa o charakterze terrorystycznym,

36 A. Golonka, Polskie rozwiazania prawne w zakresie przeciwdziałania finansowaniu terroryzmu, „Prokuratura i Prawo” 2013, nr 3, s. 100.

${ }^{37}$ Ibidem, s. 101. 
środki płatnicze, instrumenty finansowe, papiery wartościowe, wartości dewizowe, prawa majątkowe lub inne rzeczy ruchome lub nieruchomości, gromadzi, przekazuje, oferuje lub podejmuje inne czynności w zamiarze ich wykorzystania do popełnienia tego przestępstwa...”). Zwrot taki pozwoliłby z kolei na uściślenie celu działania sprawcy ${ }^{38}$.

\section{ECO-TERRORISM AS A CRIMINAL OFFENCE}

\section{Summary}

Terrorism belongs to the most serious challenges that contemporary world must face. Terroristic deeds violate the foundations of states and societies, and they are threat for their proper functioning. Simultaneously they coerce the authorities of respective states to create proper legal regulations that will penalize this phenomenon. Very wide definition of terrorism includes also so called ecological terrorism. The aim of this article is to answer the question about the place of ecological terrorism among the deeds penalized by the Polish penal code. It is important, because not all unlawful deeds that, in common language, are called "ecological terrorism" may be considered as terrorist acts in the light of the Polish penal law. Designation of a deed as one of a terrorist nature brings also important consequences from the legal point of view. The analysis of legal regulations led me to the conclusion that admittedly the Polish penal law does not reference directly to the crime of "ecoterrorism" but binding legal regulations which concern crimes of terroristic nature may be, in some scope, a ground for criminal responsibility. I also concluded that these regulations seem to be proper, and there is no need to formulate a separate definition of ecological terrorism in the Polish penal law, however some utterances included in Polish regulations may cause certain doubts. My conclusion is also that the regulations concerned the financing of crimes of a terroristic nature shall be clarified.

38 Ibidem. 